盛況で内容も多彩であった。発表は 7 日の午後からサン ロイヤルホテルの第 7 会場で始まったが，われわれの部 門がそのトップバッタを務めることになった、展示発表 であったが，会場は椅子席になっており，口述発表に近 い形の発表であった。

演題429は， $T_{2}$ 時間強調像を得るための信号を効率良 く収集する方法としていくつかのマルチエコー法がある が，これ等各々の方法，有效性について検討が加えられ ている、 $T_{2}$ 信号は $\mathrm{T}_{1}$ 信号に比べて信号強度が低いた め，初めのうちはもつぱら $\mathrm{T}_{1}$ 時間強調画像が発表され ていたが，最近では腫瘍に対して $\mathrm{T}_{2}$ 時間強調画像の方 が有効であるとする見方が強くなっており，今後は $\mathrm{T}_{2}$ に関心が向くと思われ大いに参考になる内容であった。

演題430は，MRI 装置の使用状況について述べたもの である。パルスシーケンスは IR SRが用いられてい る。この発表の中で特に強調されていることは， $T_{1}$ 時間 の変動が少ないこと．これは経時的な変化をフォローす る時に重要な点である。また局在を知るのにマルチスキ ヤンが有効であると述べられているが，これは検査時間 を短縮する手段としても効果が期待できよう。

演題431は,最近特に注目を集めているサーフェスコイ ルに関するものである，視野が狭く，深い部分の描出が むずかしい。などの久点はあるものの，得られた画像の 分解能の高さは注目に值する。他にもこのサーフェスコ イルに関する発表が数題出ており，今後大いに発展する 方法であろうと思う。これからの研究に期待したい。

演題432は，MRIに関するファントムの材料について の発表である．前回の松本での発表会でもファントムに ついての発表が何題かあったと記憶しているが, MRIの ファントムは空間分解能，コントラスト公解能などの他 $に T_{1}$ 時間， $T_{2}$ 時間などのファクタが加わり，その上温 席依存性, 磁場強度依存性, 経時変化に対する安定性な どやっかいな要素を含んでおり，まだまだ研究しなけれ ばならない点が多いようである。

演題433は,アクリル製のチャートと硫酸銅溶液を用い たファントムを使って，実際に使用している MRI 装置 の性能を測定したものである，色々むずかしい問題があ り簡単には行かないだろうが，このようなファントムが 標準化されれば，装置の保守，点検のみでなく，各装置 間の比較検討にも有用であると思われる。

MRI は無侵襲であり，他の検査にない数々の利点を持 つているので益々普及が進むと思われ，これに関する発 表もこれから増えていくことが予想される。

\section{MRI一2 性能評価}

座長 五島仁士（東芝中央病院）

\section{4. 超電導 MRI システムの開発}

東芝医用機器事業部 ○鈴木宏和

超電導磁石を用いた MRI システムを開発し，臨床治 験の目的で東芝中央病院内の東芝 MRI センターに設置 した. 現在までに, 0.35 テラと0.5テスラでの臨床治験 を終えている。この間得られたプロトン画像は $\mathrm{S} / \mathrm{N}$ が 良好で解像力のすぐれたものであった，操作性の向上も 進んだ。(1)患者のセットアップが容易になるよう寝台が $45 \mathrm{~cm}$ まで下がるようになった。(2) 2 枚の画像から位置 を決める任意方向断面撮影が可能になった。(3)撮影部位 に応じた豊富なサーフェイスコイルが揃い局所高分解能 画像が得られ，診断に有用であった。

\section{5．常電導型 NMR-CT の使用経験}

新須磨病院 ○前田文夫

〔目的〕ファントムを使用し各種パルス系列による空 間分解能と画像診断に適するイメージ条件の標準化につ いて検討した。

〔結果〕ファントムによる空間分解能は $\mathrm{T}_{E}, \mathrm{Tr}, \mathrm{Av}$ (average) の組合せの内，Av，Trの各条件に対して SAMP（samples view）を64，128，256と増せば，2.0 $\mathrm{mm}, 1.25 \mathrm{~mm}, 1.0 \mathrm{~mm}$ と向上した。人体の頭部, 腹部 では共に $\mathrm{Tr}=2100 \mathrm{msec}$ で頭部は $\mathrm{Av}=2, \mathrm{SAMP}=128$ または256を使用し腹部では呼吸性体動の影響が大きい ため $\mathrm{Av}=2, \mathrm{SAMP}=256$ よりも $\mathrm{Av}=4, \mathrm{SAMP}=128$ の 選択の方が同じ total scan time（17.9分）で良質の画像 が得られた。

\section{6．超電導 NMR の設置経験}

金沢医科大学病院中央放射線部

○香坂 誠・飛田 明 $\cdot$ 金津真也 奥 明和・定免茂明

〔発表後抄録末提出〕

\section{7. 当病院における MRI 装置の使用状況}

東京女子医科大学放射線科

○荒井 一・ 三上収三・大野伸二

川島春一・高橋康久 $\cdot$ 大谷英尚

当病院では昭和59年 9 月より本格的な臨床利用を始め, 昭和 60 年 3 月 20 日現在，1日 $4 \sim 6$ 人位で, 485例の症例 を経験した. MRIでは春椎疾患および大動脈瘤の患者に 対しては横断面以外に矢状断面や冠状断面が有効であっ た。また，MRIでは被検者の金属および呼吸等の動きに よるアーチファクトがあるので，事前の注意が必要であ 